\title{
Development of a Questionnaire to Measure Risk- taking in Decision-making by School Principals
}

\author{
By Karen Trimmer ${ }^{*}$
}

A difficult nexus can arise in positivist research when developing a model or theoretical framework that is then used to underpin the construction of measuring instruments that are subsequently used to test the assumptions underlying the model. This paper explores this nexus through consideration of a study of risk-taking in decision-making for public school principals in Western Australia (WA). A theoretical model of factors impacting on reasoned risk-taking in decision-making was developed and a questionnaire developed to measure the constructs included in the research model as there were no pre-established measurement instruments. The design of the questionnaire and development of items utilised findings from research in measurement theory to structure the items and the response scales to measure constructs in the model. Data was provided from a stratified random sample of principals in 253 schools. Rasch modeling and factor analysis were used to analyse the resultant measurement scale.

Keywords: factor analysis, decision-making, questionnaire development, Rasch modeling.

\section{Introduction}

The modernist view has an impact in organisations where it is assumed that ultimate truths exist in relation to policy positions and their impact in a range of contexts. In many organisations, policies and procedures are developed to be followed and complied with by all managers and staff regardless of the geographical location, cultural composition of staff and clients, or other local factors. The policies and procedures are deemed to provide the regulatory framework for decision-making regardless of contextual circumstances that may apply locally. In the case of West Australian public schools, principals have been provided with guidance for their decision-making by centrally developed educational policy and procedures included in a regulatory framework (Department of Education, 2004 \& 2015). Policy writers within the central office work under the assumption that policies and procedures can be developed that will apply universally to all schools and circumstances. Whilst schools are now able to apply for Independent Public School status that provides some autonomy in decision-making, the centrally developed policies have been consistently applicable to each school type, in each geographical location. The regulatory framework is deemed to provide an efficient framework for decision-making regardless of the contextual circumstances that apply locally, such as students' needs or community

\footnotetext{
* Associate Professor, University of Southern Queensland, Australia.
} 
expectations.

In this paper it is assumed that the decision-making of principals will need to be understood in terms of the educational context within each school and also the broader social structures that impact on schooling, which will include consideration of the geographical location of the school and also the cultural framework of the community in which it is located. School principals make decisions daily in relation to significant issues and strategic directions. Consideration of postmodern views would encourage decision-makers to take account of diverse viewpoints, to consider evidence that conflicted with their position on an issue or decision, and to defend these positions and decisions through logical argument. In practice many principals do this and subsequently may make decisions that are non-compliant with the established regulatory framework (Trimmer, 2003a; 2003b). They make these decisions based primarily on consideration of the individual needs of students, their school and local communities. The etic/emic contrast (Brislin, 1976; Adair \& Pastori, 2011) provides an insight into this inconsistency between corporate governance and local decision-making by principals. The regulatory framework and the policies and procedures contained within it have been developed by the organisation with a view to the etic, in that generalisations have been made that are assumed to be applicable to all school contexts and account for all behaviours and circumstances arising in schools. Principals in schools however are making their day-to-day decisions based on the emic.

\section{Literature Review}

The dichotomy created by decentralisation, in combination with increased external accountability, creates a dilemma for school principals. The impact of management demands and the requirements of central education authorities in constraining innovation in schools has been an issue of debate for many years (Sarason, 1982; Bennis \& Nanus, 1985; Sergiovanni, 2000; Starr, 2008). Principals have dual priorities they are required to meet. They must be instructional leaders to ensure that students meet achievement standards and they must simultaneously lead and manage the school as a business. These dual educational and business priorities imposed from the broader organisational executive of the schooling system impact on the leadership role of principals. Sergiovanni (2000, p.166) observes that school professionals don't have a "high tolerance for bureaucratic rituals" as they are often responding to a range of competing stakeholder demands in a politically exposed environment. Fullan (1993, p.22) concludes that "you can't mandate what matters" as educational goals are complex and require discretionary judgement. This view is supported by the research on school effectiveness and school improvement that has been consistently supportive of school-based decision-making and management (Caldwell, 1990, p.19).

In Western Australia the issue of devolution of school decision-making came to the political fore in 2001 with the publication of two government 
reports that focused on public schools. The Evaluation by Cummings and Stephenson (2001) indicated that centralised bureaucracy and a plethora of rules in the form of policy and procedures were impeding progress with local management of schools. Similarly, Robson, Harken and Hill (2001) found that the diversity that exists across education districts and schools was not recognised in the centralised administration of system-wide management policies and procedures. The report indicated that local management of schools was seen to be more responsive to local needs (Robson, Harken, \& Hill, 2001). The implication arising from these reports was that over-regulation may impede innovative decision-making by principals who require flexibility to implement responses in schools that are most appropriate to local community needs, opportunities and conditions. Caldwell (1990, p.19) expressed the view that the key to the management of the conflict around decision-making in schools that has arisen from centralisation of policies is "dependent on minimizing the number of constraining rules and regulations". Similarly, empowerment of principals to be involved in local school decision-making on policy has been cited by Wong (1997) as one of the major strategies required for reducing bureaucratic power in education.

Consistency and universalism have been lauded as critical aims in public education to ensure equity of access and opportunity for all students (Jamieson \& Wikely, 2001, p. 163). Compliance with universally required policy positions in education and schools promotes this ideal. However, as Jamieson and Wikely (2001) point out, this view is ideologically incompatible with the paradigm of responding to the individual needs of children. The current educational culture is dominated by the forces of managerialism and standards which creates a dilemma for schools in trying to make decisions to meet the learning needs of their individual school whilst meeting the externally imposed requirements of these bureaucratic influences (McMahon, 2001, p. 136). Eacott (2009, p. 3) takes this further, and states that these government policy initiatives, including professional standards, league tables, and school-based management provide evidence of the politicisation of education. These government agendas and policy initiatives place pressure on principals to comply with external requirements that may be contrary to identified strategies for education at the school level.

Research theories of risk-taking in decision-making that incorporate governance and stakeholder mechanisms, including the experience of management have been developed in a range of business contexts (Libby \& Fishburn, 1977; Wiseman \& Gomez-Meija, 1998; Wiseman, Gomez-Mejia, \& Fugate, 2000; Carpenter \& Westphal, 2001; Carpenter, Pollock, \& Leary, 2003; Nicholson, Soane, Fenton-O'Creevy, \& Willman, 2005; Petrakis, 2005). However, each of these studies has been conducted within the context of a business environment.

A literature review was used to identify key factors from previous research and together with the analysis of the qualitative data, was used in developing the research model in Figure 1 for reasoned risk-taking in decision-making by school principals. This model proposes that the independent variables: 
perception of the governance mechanism of the regulatory framework; and stakeholder characteristics; impact directly on the dependent variable: reasoned risk-taking in decision-making, and that the variable: principal experience; moderates the impact of the governance mechanism variable.

Figure 1. Research Model

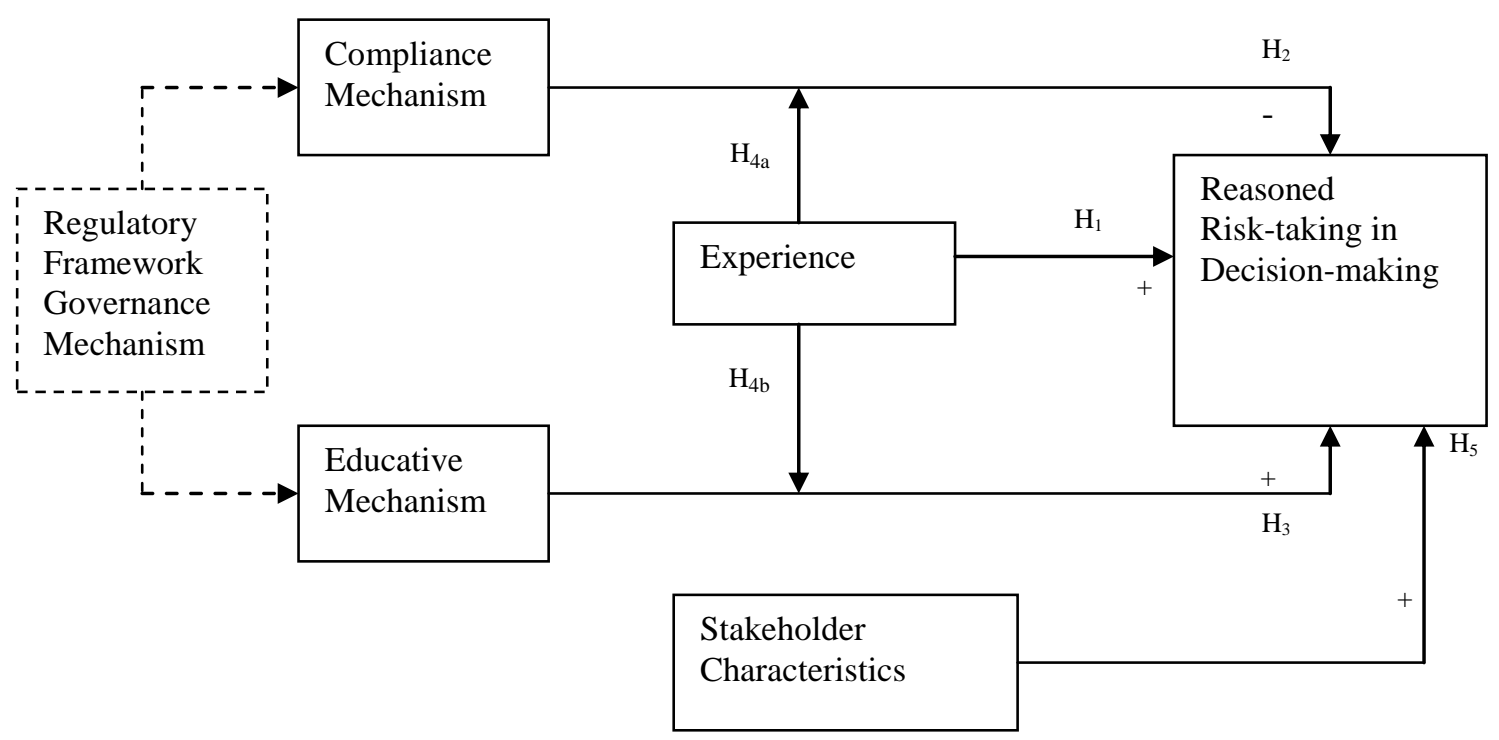

\section{Constructs Included in the Research Model}

Regulatory Framework Governance Mechanism. Research indicates that governance structures can influence how management decisions are made (Ansell \& Gash, 2008; Panova, 2008). Western Australian public school principals have been required to comply with statements of policy and procedure in a regulatory framework. The policies within the regulatory framework were developed centrally by the Department of Education and mandatory for all staff in public schools.

Compliance Mechanism or Educative Mechanism. In making decisions, the likelihood of managerial risk-taking being impacted by the decisionmakers' knowledge and values and their view of the situation as positive or negative has been well documented in business research (Hambrick \& Mason, 1984; Wiseman \& Gomez-Meija, 1998; Bazerman \& Moore, 2013). The extent of control through level of delegation of authority has also been argued as a relevant factor for many years (Singh, 1986; Zabojnik, 2002). In the context of schools, principals have the delegated authority to make managerial decisions. Each principal's perception of the purpose and value of the governance mechanism of the regulatory framework, and their level of control, impacts on their decision-making. These perceptions of risk and hence decision-making behavior are dependent of the focus of an organisation's control system. Organisational control systems that focus on the process by which decisions are made have been shown to lead to perceptions of lower risk; whereas those 
that focus on outcomes, ignoring how the decision was made, lead to perceptions of higher risk (Sitkin \& Pablo, 1992; George, Chattopadhyay, Sitkin, \& Barden, 2006). In the context, of public schools, the compliance view of the regulatory framework focuses on process, whereas an educative view focuses on providing guidance to assist a principal to achieve an appropriate outcome.

In a review of the regulatory framework (Trimmer, 2003a; 2003b) 73 per cent of principals indicated that they saw the framework as an educative tool to provide advice, instruction, guidance and clarification to assist them with decision-making. In contrast to this view, other principals considered the regulatory framework to be a compliance mechanism to control their decisionmaking. Notwithstanding their perception of its purpose, $47 \%$ of principals indicated that they saw it to be their responsibility to ensure compliance with the framework in schools and to implement its instructions.

The review also found that there was a diversity of views held by policy writers and reviewers within central office in relation to the purpose of policy within the Department. The most common views referred to setting of mandatory requirements and boundaries, and compliance with these. However, there was also an educative view that policy should be enabling rather than restrictive, through provision of a structure of common goals and support and guidance for achievement of these.

The information regarding principals' perceptions of the purpose of the regulatory framework was based on responses to the following questions (Trimmer, 2003a):

- "What is your perception of the purpose of the regulatory framework as it currently exists in the Department"

- "For what purpose have you used it or referred to it? If not, why not?"

- "What purpose do you think a regulatory framework should serve?"

- "Would this assist you more in your role as principal? How?"

- "What do you see as your responsibilities in relation to the regulatory framework?"

Experience. Carpenter, Pollock and Leary (2003) found that decisionmaking was impacted by previous experience, with individual risk-taking more likely where management had relevant experience. Differing levels of experience can effect expectations related to magnitude and probability of loss associated with taking a particular risk (Wiseman, Gomez-Mejia and Fugate, 2000). A manager with greater experience and past success with dealing with an action or circumstance, will have less uncertainty regarding the likely outcome, and the associated risk of taking the action will therefore seem more reasonable. Experienced school principals are more likely to have had the opportunity to be involved in similar past situations that provide greater knowledge to inform their future decision-making. Experienced principals would therefore be expected to have a greater propensity to engage in risk due to their reduced uncertainty and a perception of risk. Conversely, new and 
acting principals with more limited experience, would be expected to be more likely have a reduced propensity to engage in risk due to limited knowledge and greater uncertainty. As a consequence they would be more likely to refer to and comply with the regulatory framework as a guide to their decision-making.

Stakeholder Characteristic. Stakeholders have been found to have a critical role in reasoned risk-taking and strategic decision-making in business (Carpenter, Pollock, \& Leary, 2003; Carpenter \& Westphal, 2001) with influential stakeholders encouraging risk-taking by managers (Beatty \& Zajac, 1994). For school principals these stakeholders include parents and community members in the school locality. Expectations and needs of the parents and community will differ due to a range of factors including geographical location and cultural influences. Remotely located communities are impacted by both of these factors and have needs and expectations that differ from the norm. Regulatory framework policies that have been developed centrally to apply to generally applicable circumstances are less likely to align well to the expectations and needs of such a community and principals may be more inclined to take risks in decision-making to meet these.

Reasoned Risk-taking in Decision-making. Risk-taking was defined to occur when decisions were made that are not compliant with the governance mechanism of the regulatory framework. When negative outcomes arise from such decision-making, principals risk being exposed to criticism or disciplinary action for non-compliance with established policy.

Policy and procedures included within the regulatory framework were mandatory at the time of the study. However, the review found that only six percent of principals indicated that they would always comply with policy in all circumstances (Trimmer, 2003a; 2003b). Seventy percent of principals indicated that there had been instances where compliance had not been possible given the circumstances. These principals used professional discretion to make decisions, working around constraints as best they were able and taking account of local circumstances, including any geographical and cultural factors. However there was concern expressed that teachers and principals were put into a vulnerable position by policies where they could not comply. Restricted flexibility in decision-making was of particular concern in senior colleges, agricultural colleges with residential students, and remote community schools where the population of students or the community had significantly different characteristics than other schools.

The information regarding principals' perceptions of the purpose of the regulatory framework were based on responses to the following questions (Trimmer, 2003a):

- "Are there any policies or procedures that are constraining activities in schools?"

- "Are you aware of any instances where compliance was impossible given the circumstances so that professional discretion had to be used to make decisions that were contrary to the policy and procedures in the framework? What were the circumstances?" 


\section{Methodology}

The research design for the study described in this paper used a mixed methods approach. Qualitative data and the extant literature were used to model the complex inter-relationships that impact on risk-taking in decisionmaking. A quantitative approach was then used to develop a measurement instrument to enable construction of a measurement scale for the constructs identified in the model. This paper explores the complexity of development of a hypothesised model that was then used to underpin the construction of measuring instruments, where that instrument was subsequently used to test the assumptions underlying the model.

The research model presented in Figure 1 was developed by identifying key factors through the literature review and the analysis of qualitative data. The main confirmatory data for the study was collected through a survey of a larger stratified random sample of 253 principals in WA public schools that would enable quantitative analysis (Trimmer, 2003a; 2003b).

The research design included seven sequential stages:

1. Analysis of qualitative data collected through semi-structured interviews using a questionnaire pro-forma that allowed principals to self-report on aspects of decision-making and their use of the regulatory framework.

2. Development of a theoretical model based on the literature and qualitative data analysis.

3. Development of a measurement instrument to enable construction of a measurement scale for the constructs identified in the model.

Four stages of quantitative analysis were then undertaken to analyse the model and test the hypotheses.

4. Statistical analysis of each of the items on the questionnaire, including demographic variables.

5. Rasch analysis using RUMM version 2020 (Andrich, Sheridan, \& Luo, 2005 ) to ensure that the measurement scale was valid and reliable.

6. Exploratory factor analysis to investigate the correlations of items with the constructs they were designed to measure and to assist in further data reduction.

7. Analysis of the model and testing of the research hypotheses using Partial Least Squares structural equation modelling (Chin, 2001).

This paper will discuss stages 1, 3, 5 and 6 that relate to the development and analysis of the questionnaire as a measurement scale.

\section{Preliminary Data Collection and Analysis}

Preliminary data was collected for this study through face-to-face 
interviews with principals in each of 16 education districts across Western Australia. Interviews were also conducted with key stakeholder groups, including the State School Teachers' Union, professional associations for primary and secondary school administrators and the State parent and community representative body.

The interviews formed part of a review of the regulatory framework that was conducted in 2003 (Trimmer 2003a; 2003b) for the Department. The purpose of the review was to gain an understanding of the perceptions of the regulatory framework and to surface underlying issues. The interviews were semi-structured to provide focus, yet simultaneously allow an exploratory conversation regarding the interviewee's perceptions of the regulatory framework.

Interviews were held with principals in a sample of 71 schools across the state. A stratified sample of schools, of approximately four schools per district, was selected on the basis of district, geographical location, school type, and school size. This provided a sample that was representative across districts, geography, school type and size.

Table 1. Numbers of Interview Participants by Subgroups

\begin{tabular}{|l|c|c|c|c|c|c|c|}
\hline & Country & Metro & Prim & Sec & DHS & RCS & Totals \\
\hline Principals & 42 & 29 & 30 & 23 & 11 & 6 & 71 \\
\hline District & 10 & 8 & & & & & 18 \\
\hline Directors & & & & & & & \\
\hline District Office & 20 & 13 & & & & & 33 \\
\hline Managers & & & & & & & \\
\hline
\end{tabular}

Key: $\quad$ Prim $=$ Primary Schools

$\mathrm{Sec}=$ Secondary Schools

DHS $=$ District High Schools

RCS $=$ Remote Community Schools

A parallel questionnaire was developed for interviews with a purposefully selected sample of 18 central office staff. The sample included a diverse crosssection of staff involved in the development or review of policy, including policy writers and reviewers, to establish consistency of understandings held in regard to the purpose of policy within the department and the process for its development. In addition, data on principals' perceptions and use of the regulatory framework was also collected through attendance at principals' forums in two districts.

\section{Development of Questionnaire}

Measurement items were developed for this study for each of the identified constructs in the model. Measurements in existing studies related to business environments and were judged not to be transferable to an educational context. A questionnaire was therefore developed and measuring instrument constructed that was subsequently used to test the assumptions underlying the model. Whilst this limitation is acknowledged, it is an unavoidable complexity in 
exploratory research where there are not pre-established measurement instruments (Cavanagh, Kennish, \& Sturgess, 2008).

For each of the constructs in the research model, measurement items were developed with reference to the literature (see Appendix A) and the findings from the qualitative research. The design of the questionnaire and development of items utilised findings from research in measurement theory, to structure the items and the response scales to measure constructs in the model.

A series of 9 demographic items were included at the beginning of the questionnaire. These included education level, experience in education, age, and environmental and situational factors such as the experience and expertise of the principal in regard to length and type of teaching and administrative experience and the type and size of school. The geographical location and ethnic composition of the school were also included as factors likely to influence the construct of stakeholder influences.

The items in the questionnaire provided measures of principals' attitude in relation to the concepts included in the model and also measures of their behaviour. Attitude and behaviour statements fall on the same measurement continuum with behaviour statements at the higher end as they are harder items to agree to (Andrich \& Styles, 1994). The scales used in the questionnaire for this study used four point response scales with formats for items measuring attitudes of principals used the categories: Strongly Agree, Agree, Disagree, Strongly Disagree. The response format for items measuring the behaviour of principals used the categories: Always, Often, Occasionally, Never. The wording of the response sets was different to clarify the meaning for respondents.

Likert scales often use an Undecided or Neutral category as a central point between the Agree and Disagree categories. This study did not include a neutral middle category as measurement research has suggested that when placed on a continuous scale a neutral middle choice does not behave as a category between the other categories (Andrich, DeJong, \& Sheridan, 1994; Franchignoni, Giordano, Michail, \& Christodoulou, 2010). Traditionally developed Likert style items are located at the extremes of the continuum of the measurement scale with a gap in the middle. To cover this gap in the measurement scale, more ambivalent items that acknowledged contradictory ideas to be negotiated in selecting the response were included in the questionnaire design (Andrich \& Styles, 1994).

The questionnaire consisted of nine demographic questions and 49 statements: 35 items measuring attitude and 14 items measuring behaviour of principals in relation to the constructs in the model. Twenty-two of the statements were framed positively in relation to the latent trait of risk-taking in decision-making and 13 were framed negatively. Statements framed positively reflect a positive attitude toward risk-taking in decision-making, whereas statements framed negatively reflect a risk-averse attitude in decision-making. The attitude statements were presented with positive and negative statements mixed. The behaviour statements were then presented together at the end of the questionnaire. This ordering was selected as in creating a Rasch scale it is usual 
to conceptually order the items from easy to difficult before collection of the data (Waugh, 2010). As this questionnaire was constructed specifically for this study and therefore had not been used previously, it was assumed that the attitudinal items would be less difficult than the behavioural items. This assumption was confirmed through the subsequent analysis.

\section{Pilot Study}

The questionnaire was piloted with a small sample of principals from both metropolitan and remote primary and secondary schools. Fifteen principals were approached, of which 11 agreed to participate. After completing the questionnaire these principals provided feedback regarding their overall reaction, and a question by question analysis. The principals were also asked whether there were any critical issues related to decision-making that they felt had been omitted in the questionnaire or any factors that promoted risk-taking in their decision-making that they felt were not adequately covered. Amendments were made to questions based on this feedback.

The overall response to the questionnaire was positive in that respondents felt comfortable answering the questions and found the questionnaire noninvasive even though it was dealing with sensitive subject matter. Respondents also indicated that they found the topic engaging and the questions interesting to respond to. Respondents indicated that the purpose of the questionnaire and the language used was clear and not ambiguous. Principals also provided specific feedback on individual items which indicated that items were measuring what they were intended to measure.

Finally the pilot principals were asked whether there were any factors that promoted risk-taking in their decision-making that they felt were not adequately covered in the questionnaire. Taking a risk in decision-making was articulated by one respondent as simply "am I prepared to wear this" in reference to potential consequences. There was a consensus that you decide if the rules are reasonable in the circumstances and that risk-taking is justified when you make a "good enough decision", that is informed and can be defended in the circumstances, and "it leads to a better outcome". However, it was noted as a concern that some district directors, who are the line managers of principals, "don't care about outcomes as long as you follow the rules". Principals were prepared to defend their decision-making processes as they saw themselves as taking risks for sound reasons and to achieve better outcomes. However one respondent indicated that "many would be panic struck if called to account". These principals would want to be clearly distinct from "people who break rules for no good reason".

In response to the extensive feedback data gained through the pilot study significant amendments were made to the questionnaire. The refined version of the questionnaire (see Appendix B) was then used to collect data to test the hypotheses. The survey was sent to principals in a stratified random sample of 253 schools across the state from a population of 771 West Australian public schools. The strata are shown below to provide an indication of how many of 
each type of school were included in the sample and participated in the study. The sample was selected to be representative across school districts, geographical location, school type and size at a 99.5\% confidence level. The confidence level and associated error rate based on the sample size in relation to the population have been calculated for each of the strata. A total of 140 principals returned the questionnaire, a response rate of $55 \%$.

Table 2. Numbers of Principals in Sample by Strata of Geographical Location and School Type

\begin{tabular}{|c|c|c|c|c|c|}
\hline \begin{tabular}{|l} 
Geographical \\
Location
\end{tabular} & \multicolumn{2}{|c|}{ Metro } & Country & Remote & $\begin{array}{c}\text { Total } \\
\text { Respondents } \\
\end{array}$ \\
\hline Sample Size & \multicolumn{2}{|c|}{93} & 132 & 28 & 253 \\
\hline Population & 426 & 312 & & 33 & 771 \\
\hline Confidence Level & $95 \%$ & $95 \%$ & & $95 \%$ & $95 \%$ \\
\hline Error Rate & $8.98 \%$ & \multicolumn{2}{|c|}{$6.48 \%$} & $7.21 \%$ & $5.05 \%$ \\
\hline School Type & Primary & District High & Secondary & $\begin{array}{l}\text { Senior } \\
\text { College }\end{array}$ & $\begin{array}{c}\text { Agricultural } \\
\text { College }\end{array}$ \\
\hline Sample Size & 115 & 40 & 56 & 7 & 5 \\
\hline Population & 510 & 59 & 85 & 8 & 5 \\
\hline Confidence Level & $95 \%$ & $95 \%$ & $95 \%$ & $95 \%$ & $95 \%$ \\
\hline Error Rate & $8.04 \%$ & $8.79 \%$ & $7.65 \%$ & $13.1 \%$ & $0 \%$ \\
\hline
\end{tabular}

\section{Analyses}

Rasch analysis (Rasch, 1960/1980; Andrich, Sheridan, \& Luo, 2005) was used to examine the psychometric properties of the data. This component of the analysis aimed to produce a measurement scale of the attitudes and behaviours of school principals towards risk-taking in decision-making and resulted in the removal of misfitting items. For the purpose of refining the measurement items the centralised thresholds were calculated and scrutinised for items with disordered thresholds. Identified items were discarded from further analysis as the existence of disordered thresholds indicates that the items were not operating logically or consistently in regard to responses provided on the Likert scale. Data from the items with ordered thresholds were retained for further analysis.

Following the Rasch analysis, an exploratory factor analysis was conducted for the items comprising each of the constructs in the model to determine whether the items were loading onto the constructs they were developed to measure. Highly correlated items were subsequently removed and a smaller number of uncorrelated items used for each construct that adequately represented the original set of variables. Identification of the most parsimonious set of variables to include is recommended to simplify subsequent multivariate techniques (Hair, Black, Babin, Anderson, \& Tatham, 2006).

Exploratory factor analysis was conducted as it can be particularly useful 
when the researcher believes there is an underlying set of theoretical relationships but is not sure whether these underlying factors are well measured by the items (Heck, 1998). In this study the literature and qualitative data collection had provided a strong case for the theoretical constructs in the model. However, each of the items included to measure these constructs had been developed specifically for this study. There was therefore no existing validation of their measurement performance. Consideration of the items for each factor identified aspects of the construct that were consistent with the literature and preliminary findings initially used to develop the questionnaire. Components with eigenvalues greater than 1 that were supported by the theoretical literature were retained as indicators for each construct.

The sequential Rasch and factor analyses resulted in data for 12 items in the questionnaire being discarded from further analysis. However, the data retained complied with the stringent measurement criteria applied providing confidence in the constructs measured by these data in the model and improving the measurement properties of the survey instrument.

\section{Conclusion}

This paper has provided a detailed description of the processes undertaken to develop a measurement instrument and create a measurement scale. The conduct of the pilot study and subsequent feedback and adjustments, the process of administration of the finalised questionnaires and each stage of the quantitative analysis used to refine the measurement instrument were outlined. Rasch analysis to develop a robust measurement scale; and exploratory factor analysis to confirm constructs included in the model.

The Rasch analysis was undertaken to ensure that the items developed and included in the questionnaire formed a robust and reliable measurement scale of principals' attitudes and behaviours in relation to the latent trait of reasoned risk-taking in decision-making. Misfitting items that were found to have disordered thresholds were discarded from further analysis. Following the exploratory factor analysis further items were deleted providing a parsimonious set of variables that loaded highly on the underlying constructs. As a result of both the analyses only items with sound measurement properties that were most representative of the underlying constructs were retained. The rigorous statistical procedures employed resulted in the construction of a robust measurement scale that, in turn enabled the testing of the model. From the perspective of methodology, it was an edifying approach to utilise the literature and qualitative interviews in conjunction with quantitative methods to develop a measurement instrument that could then be utilized to assist with understanding the decision-making behaviour of principals in a range of diverse environments and contexts.

Whilst this paper has described the development of the measurement instrument, the results reported by Trimmer $(2011 ; 2012 ; 2014)$ showed support for the model, and were consistent with comments made by principals 
in interviews and aligned with the education literature on the importance of the role of parents and the school community in contributing to decision-making in schools (Bennis \& Nanus, 1985; Hallinger \& Heck, 1999; Anderson \& Minke, 2007; Fullan, 2007). The results were also consistent with behavioural models of risk-taking in decision-making developed in business settings (Beatty \& Zajac, 1994; Carpenter \& Westphal, 2001; Carpenter, Pollock, \& Leary, 2003; Gilley, Walters, \& Olson, 2002) and on the impact of stakeholders on management decisions.

The questionnaire developed provides an extension of the use of theory in the extant literature to the public sector context through its application to decision-making in public schools. The questionnaire was subsequently used to identify a range of factors impacting on risk-taking in decision-making by school principals. The outcomes point to significant implications for schools that require greater autonomy in governance, in particular schools with highly diverse populations, and schools in remote locations catering to Indigenous students.

\section{References}

Ansell, C., \& Gash, A. (2008). Collaborative governance in theory and practice. Journal of Public Administration Research and Theory, 18(4), 543-571.

Adair, J.K., \& Pastori, G. (2011). Developing qualitative coding frameworks for educational research: immigration, education and the Children Crossing Borders project. International Journal of Research \& Method in Education, 34(1), 31-47.

Anderson, K.J. \& Minke, K.M. (2007). Parent involvement in education: toward an understanding of parents' decision making. The Journal of Educational Research, 100(5),311-323.

Andrich, D., DeJong, J.H.A.L., \& Sheridan, B. (1994). Diagnostic opportunities with the Rasch model for ordered response categories. Paper read at IPN Symposium on applications of latent trait and latent class models in the social sciences, Germany.

Andrich, D., Sheridan, B., \& Luo, G. (2005). Rasch Unidimensional Measurement Model (RUMM2020): a windows based program using Rasch measurement. RUMM Laboratory, Perth.

Andrich, D., \& Styles, I. (1994). The structural relationship between attitude and behaviour statements from the unfolding perspective. Paper read at 23 International Congress of Applied Psychology, Madrid, Spain.

Bacic, I.L.Z., Bregt, A.K., \& Rossiter, D.G. (2006). A participatory approach for integrating risk assessment into rural decision-making: A case study in Santa Catarina, Brazil. Agricultural Systems, 87, 229-244.

Baird, I.S., \& Thomas, H. (1985). Toward a contingency model of strategic risk taking. Academy of Management Review, 10(2), 230-243.

Bazerman, M.H., \& Moore, D.A. (2013). Judgment in managerial decision making. 8th Edn. Wiley.

Beatty, R.P., \& Zajac, E.J. (1994). Managerial incentives, monitoring and risk bearing: a study of executive compensation, ownership, and board structure in initial public offerings. Administrative Science Quarterly, 39, 313-335.

Bennis, W., \& Nanus, B. (1985). Leaders: The strategies for taking charge. New 
York: Harper and Row.

Brislin, R.W. (1976). Comparative research methodology: Cross-cultural studies. International Journal of Psychology, 11(3), 215-229.

Caldwell, B. J. (1990). School-based decision-making and management: International developments. In J. Chapman (Ed.), School-based Decision-making and Management. London: The Falmer Press.

Carpenter, M.A., Pollock, T.G., \& Leary, M.M. (2003). Testing a model of reasoned risk-taking: governance, the experience of principals and agents, and global strategy in high-technology IPO firms. Strategic Management Journal, 24, 803820.

Carpenter, M.A., \& Westphal, J.D. (2001). The strategic context of external network ties: Examining the impact of director appointments on board involvement in strategic decision making. Academy of Management Journal, 44(4), 639-660.

Cavanagh, R.F., Kennish, P., \& Sturgess, K. (2008). Measuring student engagement in classroom learning: Theoretical frameworks and teacher instrument piloting. Perth: Curtin University of Technology.

Chin, W.W. (2001). PLS Graph User's Guide 3.0.

Cummings, R., \& Stephenson, K. (2001). Evaluation study of the local management of schools pilot study. Western Australia: Department of Education.

Deci, E., \& Ryan, R. (1987). The support of autonomy and the control of behaviour. Journal of Personality and Social Psychology, 53(6), 1024-1037.

Department of Education and Training. (2004). Regulatory Framework [Web site and CD ROM]. Perth, Western Australia, May 2004.

Department of Education. (2015). Policies. Retrieved from http://bit.ly/2g4Dfa9.

Eacott, S. (2009). New look leaders or a new look at leadership. Paper read at Australian Association for Research in Education. Canberra.

Franchignoni, F., Giordano, A., Michail, X., \& Christodoulou, N. (2010). Practical lessons learned from use of Rasch analysis in the assessment of outcome measures. Revista da Sociedade Portuguesa de Medicina Física e de Reabilitação, 19(2), 5-12.

Fullan, M. (1993). Change Forces Probing the Depths of Educational Reform. London: The Falmer Press.

Fullan, M. (2007). The new meaning of educational change, $4^{\text {th }}$ ed. New York: Teachers College Press.

Franken, I.H.A., \& Muris, P. (2004). Individual differences in decision-making. Personality and Individual Differences, 39, 991-998.

George, E., Chattopadhyay, P., Sitkin, S. \& Barden, J. (2006). Cognitive underpinnings of institutional persistence and change: A framing perspective, Academy of Management Review, 31(2), 347-365.

Gilley, K. M., Walters, B.A., \& Olson, B.J. (2002). Top management team risk taking propensities and firm performance: Direct and moderating effects. Journal of Business Strategies, 19(2), 95-115.

Hair, J.F. Jr, Black, W.C., Babin, B.J., Anderson, R.E., \& Tatham, R.L. (2006). Multivariate Data Analysis, $6^{\text {th }}$ ed. New Jersey: Pearson Education International.

Hallinger, P., \& Heck, R. (1999). Can leadership enhance school effectiveness? In Educational Management: redefining theory, policy and practice, T. Bush, D. E. Bell, R. Bolam, R. Glatter and P. Ribbins (Eds.). London: Paul Chapman Publishing.

Hambrick, D.C., \& Mason P.A. (1984). Upper echelons: The organization as a reflection of its top managers. Academy of Management Review, 9, 193-206.

Heck, R.H. (1998). Factor analysis: Exploratory and confirmatory approaches. In G. 
A. Marcoulides (Ed.), Modern Methods for Business Research. New Jersey: Lawrence Erlbaum Associates.

Jamieson, I., \& Wikely, F. (2001). A contextual perspective: Fitting school round the needs of students. In A. Harris and N. Bennett (Eds.), School Effectiveness and School Improvement: Alternative Perspectives. London: Continuum.

Libby, R., \& Fishburn, P.C. (1977). Behavioural models of risk taking in business decisions: A survey and evaluation. Journal of Accounting Research, 15, 272292.

MacCrimmon, K.R., \& Wehrung, D.A. (1990). Characteristics of risk taking executives. Management Science, 36 (4), 422-435.

MacNeill, N., \& Silcox, S. (2006). Earned autonomy for schools. [unpublished paper].

McMahon, A. (2001). A cultural perspective on school effectiveness, school improvement and teacher professional development. In A. Harris and N. Bennett (Eds.), School Effectiveness and School Improvement: alternative perspectives. London: Continuum.

Nicholson, N., Soane, E., Fenton-O'Creevy, M., \& Willman, P. (2005). Personality and domain-specific risk taking. Journal of Risk Research, 8(2), 157-176.

Panova, A. (2008). Governance structures and decision making in Russian higher education institutions. Russian Social Science Review, 49(5), 76-93.

Petrakis, P E. (2005). Risk perception, risk propensity and entrepreneurial behaviour: The Greek case. The Journal of American Academy of Business, 7(1), 233-242.

Rasch, G. (1960/1980). Probabilistic models for some intelligence and attainment tests. Chicago: University of Chicago Press.

Reeve, J., Nix, G., \& Hamm, D. (2003). Testing models of the experience of selfdetermination in intrinsic motivation and the conundrum of choice. Journal of Educational Psychology, 95(2), 375-392.

Robson, A., Harken, E., \& Hill, C. (2001). Investing in government schools: Putting children first. Perth: Department of Education Services.

Sarason, S. (1982). The culture of school and the problem of change, Revised ed. Needham Heights: Allyn and Bacon.

Sergiovanni, T J. (2000). The lifeworld of leadership: creating culture, community and personal meaning in our schools. San Francisco: Jossey-Bass Publishers.

Singh, J. (1986). Performance, slack, and risk taking in organizational decision making. The Academy of Management Journal, 29(3):562-585.

Sitkin, S.B., \& Pablo, A.L. (1992). Reconceptualizing the determinants of risk behaviour. Academy of Management Review, 17(1), 9-38.

Soane, E., \& Chmiel, N. (2005). Are risk preferences consistent? The influence of decision domain and personality. Personality and Individual Differences, 38, 1781-1791.

Starr, K. (2008). Whose risk? 'Managing' risk in the principalship. Paper read at Australian Association for Research in Education. Brisbane.

Trimmer, K. (2003a). Review of the regulatory framework, Department of Education, Perth, Western Australia.

Trimmer, K. (2003b). Review of the West Australian Department of Education Regulatory Framework. Paper read at Australian Association of Research in Education Conference, at Auckland, New Zealand.

Trimmer, K. (2011). Non-compliance by school principals: the effects of experience, stakeholder characteristics and governance mechanisms on reasoned risk-taking in decision-making. Thesis for award of Doctor of Business Administration, Curtin University of Technology.

Trimmer, K. (2012). Policy for all? The impact of centrally developed, universally 
applied policy on decision-making in Western Australian public schools. Innovative Research in a Changing and Challenging World International Conference Proceedings, Phuket, Thailand 16-18 May 2012.

Trimmer, K. (2014). Decision-making by school principals and education researchers: The dilemma of reverse coding in structural equation modeling and its resolution in a study of risk-taking in decision-making for school principals, Athens Journal of Education, 1(1), Athens: The Athens Institute for Education and Research. ISSN:2241-7958.

Vlek, C., \& Stallen, P. (1980). Rational and personal aspects of risk. Acta sychologica 45, 273-300.

Waugh, R.F. (2010). Specialized Rasch measures applied at the forefront of education. New York: Nova Science Publishers, Inc.

Whiteley, A. (2004). Enlightenment the age of reason. Lecture notes, Curtin Graduate Business School, Perth.

Wirtz, V., Cribb, A., \& Barber, N. (2005). Reimbursement decisions in health policyextending our understanding of the elements of decision-making. Health Policy, 73, 330-338.

Wiseman, R.M., \& Gomez-Mejia, L.R. (1998). A behavioral agency model of managerial risk taking. Academy of Management Review, 23(1), 133-153.

Wiseman, R.M., Gomez-Mejia, L.R \& Fugate, M. (2000). Rethinking compensation risk. In S. L. Rynes and B. Gerhart (Eds), Compensation in Organizations. San Francisco: Josey-Bass.

Wong, K.K. (1997). Bureaucracy and school effectiveness. In L. J. Saha (Ed.), International Encyclopedia of the Sociology of Education. Canberra: Pergamon.

Zabojnik, J. (2002). Centralized and decentralized decision making in organizations. Journal of Labor Economics, 20(1), 1-22. 
Appendix A. Framework for Development of Questionnaire

\begin{tabular}{|c|c|c|c|}
\hline Construct & $\begin{array}{l}\text { Key Issues from } \\
\text { Literature/ Past } \\
\text { research }\end{array}$ & $\begin{array}{l}\text { Proposed Items for Survey } \\
\text { Questionnaire }\end{array}$ & Reference/Source \\
\hline \multirow[t]{8}{*}{$\begin{array}{l}\text { Compliance } \\
\text { Mechanism }\end{array}$} & \multirow[t]{7}{*}{$\begin{array}{l}\text { Level of delegation } \\
\text { Authority/ control } \\
\text { over decision- } \\
\text { making process }\end{array}$} & $\begin{array}{l}\text { The principal is accountable } \\
\text { for ensuring that decisions are } \\
\text { made in line with the School } \\
\text { Education Act and } \\
\text { Regulations and policy } \\
\text { included in the regulatory } \\
\text { framework. }\end{array}$ & $\begin{array}{l}\text { (Deci \& Ryan 1987) } \\
\text { (Hambrick \& Mason } \\
\text { 1984) } \\
\text { (Singh 1986) } \\
\text { (Trimmer 2003a) } \\
\text { (Trimmer 2003b) } \\
\text { (Wiseman \& Gomez- } \\
\text { Mejia 1998) }\end{array}$ \\
\hline & & $\begin{array}{l}\text { The regulatory framework } \\
\text { constrains me in my role of } \\
\text { principal in making decisions } \\
\text { that meet the needs of this } \\
\text { school and its students. }\end{array}$ & $\begin{array}{l}\text { (Singh 1986) } \\
\text { (Trimmer 2003a) } \\
\text { (Trimmer 2003b) } \\
\text { (Wiseman \& Gomez- } \\
\text { Mejia 1998) }\end{array}$ \\
\hline & & $\begin{array}{l}\text { Compliance with centralised } \\
\text { policy in the regulatory } \\
\text { framework constrains me } \\
\text { from making the most } \\
\text { appropriate decisions to meet } \\
\text { the local needs of this school }\end{array}$ & $\begin{array}{l}\text { (MacNeill \& Silcox } \\
\text { 2006) } \\
\text { (Singh 1986) } \\
\text { (Trimmer 2003a) } \\
\text { (Trimmer 2003b) } \\
\text { (Wiseman \& Gomez- } \\
\text { Mejia 1998) } \\
\text { Feedback from pilot } \\
\text { of the questionnaire }\end{array}$ \\
\hline & & $\begin{array}{l}\text { As principal, I have control } \\
\text { over decision-making in the } \\
\text { school. }\end{array}$ & $\begin{array}{l}\text { (Deci \& Ryan 1987) } \\
\text { (Hambrick \& Mason } \\
\text { 1984) } \\
\text { (Reeve, Nix \& } \\
\text { Hamm 2003) } \\
\text { (Vlek \& Stallen } \\
\text { 1980) \& } \\
\end{array}$ \\
\hline & & $\begin{array}{l}\text { The consequences of } \\
\text { decisions made in line with } \\
\text { the regulatory framework are } \\
\text { beyond my control. }\end{array}$ & $\begin{array}{l}\text { (Deci \& Ryan 1987) } \\
\text { (Reeve, Nix \& } \\
\text { Hamm 2003) } \\
\text { (Vlek \& Stallen } \\
\text { 1980) }\end{array}$ \\
\hline & & $\begin{array}{l}\text { Principals have the authority } \\
\text { to choose the appropriate } \\
\text { course of action for the } \\
\text { circumstances in their school. }\end{array}$ & $\begin{array}{l}\text { (Deci \& Ryan 1987) } \\
\text { (Hambrick \& Mason } \\
1984) \\
(\text { Singh 1986) }\end{array}$ \\
\hline & & $\begin{array}{l}\text { Authority to make decisions is } \\
\text { delegated to principals. }\end{array}$ & $\begin{array}{l}\text { (Deci \& Ryan 1987) } \\
\text { (Hambrick \& Mason } \\
\text { 1984) } \\
\text { (MacNeill \& Silcox } \\
\text { 2006) } \\
\text { (Singh 1986) } \\
\text { (Trimmer 2003a) } \\
\text { (Trimmer 2003b) } \\
\end{array}$ \\
\hline & $\begin{array}{l}\text { Focus } \\
\text { governance } \\
\text { framework } \\
\text { process } \\
\text { compliance }\end{array}$ & $\begin{array}{l}\text { The purpose of the regulatory } \\
\text { framework is to assure } \\
\text { compliance by schools to } \\
\text { established policies and } \\
\text { procedures. }\end{array}$ & $\begin{array}{l}\text { (Deci \& Ryan 1987) } \\
\text { (Trimmer 2003a) } \\
\text { (Trimmer 2003b) } \\
\text { (Wiseman \& Gomez- } \\
\text { Mejia 1998) }\end{array}$ \\
\hline
\end{tabular}




\begin{tabular}{|c|c|c|c|}
\hline Construct & $\begin{array}{l}\text { Key Issues } \text { from } \\
\text { Literature/ } \\
\text { research }\end{array}$ & $\begin{array}{l}\text { Proposed Items for Survey } \\
\text { Questionnaire }\end{array}$ & Reference/Source \\
\hline & & $\begin{array}{l}\text { In making decisions I refer to } \\
\text { training/PD I have had about } \\
\text { interpreting and applying the } \\
\text { regulatory framework. }\end{array}$ & $\begin{array}{l}\text { (Libby \& } \text { Fishburn } \\
\text { 1976) } \\
\text { (Sitkin \& } \quad \text { Pablo } \\
\text { 1992) } \\
\text { (Wiseman \& } \text { Gomez- } \\
\text { Mejia 1998) }\end{array}$ \\
\hline & & $\begin{array}{l}\text { It is important that principals } \\
\text { in all schools are making } \\
\text { consistent decisions. }\end{array}$ & $\begin{array}{l}\text { (Libby \& Fishburn } \\
\text { 1976) } \\
\text { (Sitkin \& Pablo } \\
\text { 1992) } \\
\text { (Trimmer 2003a) } \\
\text { (Trimmer 2003b) }\end{array}$ \\
\hline & & $\begin{array}{l}\text { When making decisions I try } \\
\text { to comply with what I believe } \\
\text { the Department would prefer } \\
\text { me to do. }\end{array}$ & $\begin{array}{l}\text { (Libby \& Fishburn } \\
\text { 1976) } \\
\text { (Sitkin \& Pablo } \\
\text { 1992) } \\
\text { (Whiteley A } \\
\text { 2004) }\end{array}$ \\
\hline & & $\begin{array}{l}\text { In making decisions I am } \\
\text { obligated to comply with } \\
\text { courses of action prescribed in } \\
\text { the regulatory framework. }\end{array}$ & $\begin{array}{l}\text { (Deci \& Ryan 1987) } \\
\text { (Sitkin \& Pablo } \\
\text { 1992) } \\
\text { (Trimmer 2003a) } \\
\text { (Trimmer 2003b) }\end{array}$ \\
\hline & & $\begin{array}{l}\text { I feel pressured to always } \\
\text { make decisions in line with } \\
\text { the regulatory framework. }\end{array}$ & $\begin{array}{l}\text { (Deci \& Ryan 1987) } \\
\text { (Reeve, Nix \& } \\
\text { Hamm 2003) } \\
\text { (Wiseman \& Gomez- } \\
\text { Mejia 1998) }\end{array}$ \\
\hline & & $\begin{array}{l}\text { I am concerned about the } \\
\text { possibility of personal } \\
\text { litigation if I do not comply } \\
\text { with all of the policy and } \\
\text { procedures in the regulatory } \\
\text { framework }\end{array}$ & $\begin{array}{l}\text { (Wirtz, Cribb \& } \\
\text { Barber 2005) }\end{array}$ \\
\hline & & $\begin{array}{l}\text { Making decisions in line with } \\
\text { the regulatory framework } \\
\text { assures that they can be } \\
\text { publicly and legally defended } \\
\text { regardless of the outcome of } \\
\text { the decision. }\end{array}$ & $\begin{array}{l}\text { (Wirtz, Cribb \& } \\
\text { Barber 2005) } \\
\text { Feedback from pilot } \\
\text { of the questionnaire }\end{array}$ \\
\hline $\begin{array}{l}\text { Educative } \\
\text { Mechanism }\end{array}$ & $\begin{array}{lr}\text { Focus } & \text { of } \\
\text { governance } & \\
\text { framework } & \text { on } \\
\text { outcomes } & \text { and } \\
\text { provision } & \text { of } \\
\text { assistance } & \text { to } \\
\text { enable decision- } \\
\text { making }\end{array}$ & $\begin{array}{l}\text { The purpose of the regulatory } \\
\text { framework is to provide } \\
\text { advice, instruction, guidance } \\
\text { and clarification to assist with } \\
\text { decision-making. }\end{array}$ & $\begin{array}{l}\text { (Deci \& Ryan 1987) } \\
\text { (Hambrick \& Mason } \\
\text { 1984) } \\
\text { (Sitkin \& Pablo } \\
\text { 1992) (Trimmer } \\
\text { 2003a) } \\
\text { (Trimmer 2003b) } \\
\text { (Wiseman \& Gomez- } \\
\text { Mejia 1998) }\end{array}$ \\
\hline
\end{tabular}




\begin{tabular}{|c|c|c|c|}
\hline Construct & $\begin{array}{l}\text { Key Issues from } \\
\text { Literature/ Past } \\
\text { research }\end{array}$ & $\begin{array}{l}\text { Proposed Items for Survey } \\
\text { Questionnaire }\end{array}$ & Reference/Source \\
\hline & & $\begin{array}{l}\text { I refer to the regulatory } \\
\text { framework to assist in making } \\
\text { decisions that achieve } \\
\text { outcomes for students, the } \\
\text { school and community. }\end{array}$ & $\begin{array}{l}\text { (Deci \& Ryan 1987) } \\
\text { (Hambrick \& Mason } \\
\text { 1984) }\end{array}$ \\
\hline & & $\begin{array}{l}\text { I often use the non-mandatory } \\
\text { information and guidelines, in } \\
\text { addition to mandatory policy } \\
\text { and procedures, to assist in } \\
\text { making decisions. }\end{array}$ & $\begin{array}{l}\text { (Sitkin \& Pablo } \\
\text { 1992) } \quad \text { (Trimmer } \\
\text { 2003a) } \\
\text { (Trimmer 2003b) }\end{array}$ \\
\hline & & $\begin{array}{l}\text { The regulatory framework } \\
\text { assists me in my role of } \\
\text { principal to make decisions } \\
\text { that meet the needs of this } \\
\text { school and its students. }\end{array}$ & $\begin{array}{l}\text { (Hambrick \& Mason } \\
\text { 1984) } \\
\text { (Sitkin \& Pablo } \\
\text { 1992) (Trimmer } \\
\text { 2003a) } \\
\text { (Trimmer 2003b) } \\
\text { (Wiseman \& Gomez- } \\
\text { Mejia 1998) }\end{array}$ \\
\hline & & $\begin{array}{l}\text { I am satisfied that the policies } \\
\text { in the regulatory framework } \\
\text { support outcomes I want to } \\
\text { achieve in this school. }\end{array}$ & $\begin{array}{l}\text { (Deci \& Ryan 1987) } \\
\text { (Hambrick \& Mason } \\
\text { 1984) } \\
\text { (Sitkin \& Pablo } \\
\text { 1992) }\end{array}$ \\
\hline Experience & $\begin{array}{l}\text { Length of } \\
\text { experience } \\
\text { Relevance and } \\
\text { type of experience }\end{array}$ & $\begin{array}{l}\text { How long have you been } \\
\text { employed in the role of } \\
\text { principal? }\end{array}$ & $\begin{array}{l}\text { (Carpenter, Pollock } \\
\text { \& Leary 2003) } \\
\text { (MacCrimmon \& } \\
\text { Wehrung 1990) } \\
\text { (Trimmer 2003a) } \\
\text { (Trimmer 2003b) } \\
\text { (Wiseman, Gomez- } \\
\text { Mejia \& Fugate } \\
\text { 2000) }\end{array}$ \\
\hline & & $\begin{array}{l}\text { How long have you been } \\
\text { employed as a teacher/school } \\
\text { administrator? }\end{array}$ & $\begin{array}{l}\text { (Carpenter, Pollock } \\
\text { \& Leary 2003) } \\
\text { (MacCrimmon \& } \\
\text { Wehrung 1990) } \\
\text { (Trimmer 2003a) } \\
\text { (Trimmer 2003b) } \\
\text { (Wiseman, Gomez- } \\
\text { Mejia \& Fugate } \\
\text { 2000) }\end{array}$ \\
\hline & & $\begin{array}{l}\text { Do you hold the role of } \\
\text { principal substantively? }\end{array}$ & $\begin{array}{l}\text { (Soane \& Chmiel } \\
\text { 2005) } \\
\text { (Trimmer 2003a) } \\
\text { (Trimmer 2003b) } \\
\text { (Wiseman, Gomez- } \\
\text { Mejia \& Fugate } \\
\text { 2000) }\end{array}$ \\
\hline & & School Type & $\begin{array}{l}\text { (Trimmer 2003a) } \\
\text { (Trimmer 2003b) }\end{array}$ \\
\hline
\end{tabular}




\begin{tabular}{|c|c|c|c|}
\hline Construct & $\begin{array}{lr}\text { Key Issues } & \text { from } \\
\text { Literature/ } & \text { Past } \\
\text { research } & \\
\end{array}$ & $\begin{array}{l}\text { Proposed Items for Survey } \\
\text { Questionnaire }\end{array}$ & Reference/Source \\
\hline & & $\begin{array}{l}\text { When making decisions I } \\
\text { refer to past experience where } \\
\text { I have made decisions about } \\
\text { similar situations. }\end{array}$ & $\begin{array}{l}\text { (Bacic, Bregt \& } \\
\text { Rossiter 2006) } \\
\text { (Carpenter, Pollock } \\
\text { \& Leary 2003) } \\
\text { (Franken \& Muris } \\
\text { 2004) } \\
\text { (Libby \& Fishburn } \\
\text { 1977) } \\
\text { (Wiseman, Gomez- } \\
\text { Mejia \& Fugate } \\
\text { 2000) \& }\end{array}$ \\
\hline & & $\begin{array}{l}\text { I have a lot of experience in } \\
\text { making decisions as a school } \\
\text { leader. }\end{array}$ & $\begin{array}{l}\text { (Carpenter, Pollock } \\
\text { \& Leary 2003) } \\
\text { (Franken \& Muris } \\
\text { 2004) } \\
\text { (Libby \& Fishburn } \\
\text { 1977) } \\
\text { (Trimmer 2003a) } \\
\text { (Trimmer 2003b) } \\
\text { (Wiseman, Gomez- } \\
\text { Mejia \& Fugate } \\
\text { 2000) \& }\end{array}$ \\
\hline & & $\begin{array}{l}\text { My capacity to make } \\
\text { decisions was a key criterion } \\
\text { in being selected for this } \\
\text { position as principal. }\end{array}$ & $\begin{array}{l}\text { (MacCrimmon \& } \\
\text { Wehrung 1990) } \\
\text { (Soane \& Chmiel } \\
\text { 2005) }\end{array}$ \\
\hline & & $\begin{array}{l}\text { I don't have a great deal of } \\
\text { experience in making } \\
\text { decisions as a principal. }\end{array}$ & $\begin{array}{l}\text { (Carpenter, Pollock } \\
\text { \& Leary 2003) } \\
\text { (Franken \& Muris } \\
\text { 2004) } \\
\text { (Libby \& Fishburn } \\
\text { 1977) } \\
\text { (Trimmer 2003a) } \\
\text { (Trimmer 2003b) } \\
\text { (Wiseman, Gomez- } \\
\text { Mejia \& Fugate } \\
\text { 2000) \& }\end{array}$ \\
\hline & $\begin{array}{l}\text { Past success in } \\
\text { risk-taking }\end{array}$ & $\begin{array}{l}\text { When I have made decisions } \\
\text { that were contrary to the } \\
\text { policy and procedures in the } \\
\text { framework I have been able to } \\
\text { meet the outcomes I was } \\
\text { trying to achieve. }\end{array}$ & $\begin{array}{l}\text { (Wiseman, Gomez- } \\
\text { Mejia \& Fugate } \\
2000) \\
\text { (Trimmer 2003a) } \\
\text { (Trimmer 2003b) }\end{array}$ \\
\hline & & $\begin{array}{l}\text { When I have made decisions } \\
\text { that were contrary to the } \\
\text { policy and procedures in the } \\
\text { framework there have been } \\
\text { repercussions from district or } \\
\text { central office to sanction my } \\
\text { decision. }\end{array}$ & $\begin{array}{l}\text { (Carpenter, Pollock } \\
\& \text { Leary 2003) } \\
\text { (Wiseman, Gomez- } \\
\text { Mejia \& Fugate } \\
2000 \text { ) }\end{array}$ \\
\hline
\end{tabular}




\begin{tabular}{|c|c|c|c|}
\hline Construct & $\begin{array}{lr}\text { Key Issues } & \text { from } \\
\text { Literature/ } & \text { Past } \\
\text { research } & \\
\end{array}$ & $\begin{array}{l}\text { Proposed Items for Survey } \\
\text { Questionnaire }\end{array}$ & Reference/Source \\
\hline & & $\begin{array}{l}\text { In my experience, I have } \\
\text { found that I am best placed to } \\
\text { make decisions concerning } \\
\text { my school. }\end{array}$ & $\begin{array}{l}\text { (Franken \& Muris } \\
\text { 2004) }\end{array}$ \\
\hline & & $\begin{array}{l}\text { In my experience, I have } \\
\text { found that centrally made } \\
\text { policies are not always } \\
\begin{array}{l}\text { appropriate to } \\
\text { circumstances. }\end{array}\end{array}$ & $\begin{array}{l}\text { (Carpenter, Pollock } \\
\& \text { Leary 2003) }\end{array}$ \\
\hline & & $\begin{array}{l}\text { Taking account of the } \\
\text { experience of myself and } \\
\text { other principals I know in } \\
\text { similar situations is as } \\
\text { important as the stated policy } \\
\text { in making decisions about } \\
\text { individual cases. }\end{array}$ & $\begin{array}{l}\text { (Carpenter, Pollock } \\
\text { \& Leary 2003) } \\
\text { (Wirtz, Cribb \& } \\
\text { Barber 2005) }\end{array}$ \\
\hline & & $\begin{array}{l}\text { I have had positive feedback } \\
\text { from Directors about my } \\
\text { decision-making. }\end{array}$ & $\begin{array}{l}\text { (Carpenter, Pollock } \\
\& \text { Leary 2003) } \\
\text { (Wiseman, Gomez- } \\
\text { Mejia \& Fugate } \\
\text { 2000) }\end{array}$ \\
\hline & & $\begin{array}{l}\text { I have been disciplined or } \\
\text { chastised by a Director } \\
\text { regarding a decision I have } \\
\text { made. }\end{array}$ & $\begin{array}{l}\text { (Carpenter, Pollock } \\
\& \text { Leary 2003) } \\
\text { (Wiseman, Gomez- } \\
\text { Mejia \& Fugate } \\
\text { 2000) }\end{array}$ \\
\hline \multirow[t]{6}{*}{\begin{tabular}{|l|} 
Stakeholder \\
Characteristics
\end{tabular}} & \multirow[t]{2}{*}{$\begin{array}{l}\text { Geographical } \\
\text { location of school }\end{array}$} & District & $\begin{array}{l}\text { (Robson, Harken \& } \\
\text { Hill 2001) } \\
\text { (Trimmer 2003a) } \\
\text { (Trimmer 2003b) }\end{array}$ \\
\hline & & $\begin{array}{l}\text { Rural/remote location of } \\
\text { school. }\end{array}$ & $\begin{array}{l}\text { (Cummings \& } \\
\text { Stephenson 2001) } \\
\text { (Robson, Harken \& } \\
\text { Hill 2001) } \\
\text { (Trimmer 2003a) } \\
\text { (Trimmer 2003b) }\end{array}$ \\
\hline & \multirow{3}{*}{$\begin{array}{l}\text { School size } \\
\text { Diversity } \\
\text { cultural of } \\
\text { composition of } \\
\text { school community }\end{array}$} & $\begin{array}{l}\text { School size } \\
\text { students) }\end{array}$ & $\begin{array}{l}\text { (Cummings \& } \\
\text { Stephenson 2001) } \\
\text { (Trimmer 2003a) } \\
(\text { Trimmer 2003b) }\end{array}$ \\
\hline & & $\begin{array}{l}\text { The proportion of students at } \\
\text { this school who are of } \\
\text { Aboriginal or Torres Strait } \\
\text { Islander descent. }\end{array}$ & $\begin{array}{l}\text { (Cummings \& } \\
\text { Stephenson 2001) } \\
\text { (Robson, Harken \& } \\
\text { Hill 2001) }\end{array}$ \\
\hline & & $\begin{array}{l}\text { The proportion of students at } \\
\text { this school who are from } \\
\text { culturally and linguistically } \\
\text { diverse backgrounds. }\end{array}$ & $\begin{array}{l}\text { (Cummings \& } \\
\text { Stephenson 2001) } \\
\text { (Robson, Harken \& } \\
\text { Hill 2001) }\end{array}$ \\
\hline & $\begin{array}{l}\text { Diversity of } \\
\text { cultural } \\
\text { composition of } \\
\text { school community }\end{array}$ & $\begin{array}{l}\text { The characteristics of this } \\
\text { school community are very } \\
\text { different from other schools I } \\
\text { have experienced. }\end{array}$ & $\begin{array}{l}\text { (Bacic, Bregt \& } \\
\text { Rossiter 2006) } \\
\text { (Carpenter, Pollock } \\
\text { \& Leary 2003) }\end{array}$ \\
\hline
\end{tabular}




\begin{tabular}{|c|c|c|c|}
\hline Construct & $\begin{array}{l}\text { Key Issues from } \\
\text { Literature/ } \\
\text { research }\end{array}$ & $\begin{array}{l}\text { Proposed Items for Survey } \\
\text { Questionnaire }\end{array}$ & Reference/Source \\
\hline & \multirow[t]{7}{*}{ Stakeholder input } & $\begin{array}{l}\text { I could not be certain about } \\
\text { the preferences of the school } \\
\text { community in all } \\
\text { circumstances. }\end{array}$ & $\begin{array}{l}\text { (Bacic, Bregt \& } \\
\text { Rossiter 2006) }\end{array}$ \\
\hline & & $\begin{array}{l}\text { Parents and community } \\
\text { members frequently ask } \\
\text { questions or raise concerns } \\
\text { about policy and procedures } \\
\text { with me. }\end{array}$ & $\begin{array}{l}\text { (Beatty \& Zajac } \\
\text { 1994) } \\
\text { (Carpenter, Pollock } \\
\text { \& Leary 2003) } \\
\text { (Trimmer 2003a) } \\
\text { (Trimmer 2003b) }\end{array}$ \\
\hline & & $\begin{array}{l}\text { Parents and community } \\
\text { members frequently have } \\
\text { input into the decision-making } \\
\text { processes about issues arising } \\
\text { in the school. }\end{array}$ & $\begin{array}{l}\text { (Beatty \& Zajac } \\
\text { 1994) } \\
\text { (Carpenter, Pollock } \\
\& \quad \text { Leary 2003) } \\
\text { (Trimmer 2003a) } \\
\text { (Trimmer 2003b) } \\
\text { (Carpenter } \& \\
\text { Westphal 2001) } \\
\text { (Trimmer 2003a) } \\
\text { (Trimmer 2003b) }\end{array}$ \\
\hline & & $\begin{array}{l}\text { seek input from the } \\
\text { community as I have an } \\
\text { incomplete understanding of } \\
\text { their needs. }\end{array}$ & $\begin{array}{ll}\text { Bacic, Bregt } & \& \\
\text { Rossiter 2006) } & \\
\text { (Cummings } & \& \\
\text { Stephenson 2001) } & \end{array}$ \\
\hline & & $\begin{array}{l}\text { The needs of this school } \\
\text { community are unique. }\end{array}$ & $\begin{array}{l}\text { Cummings \& } \\
\text { Stephenson 2001) } \\
\text { (Robson, Harken \& } \\
\text { Hill 2001) } \\
(\text { Trimmer 2003a) } \\
\text { (Trimmer 2003b) } \\
\end{array}$ \\
\hline & & $\begin{array}{l}\text { My decision-making in this } \\
\text { school is influenced by the } \\
\text { geographical location of the } \\
\text { school. }\end{array}$ & $\begin{array}{l}\text { Cummings } \\
\text { Stephenson 2001) } \\
\text { (Robson, Harken \& } \\
\text { Hill 2001) } \\
\text { (Trimmer 2003a) } \\
\text { (Trimmer 2003b) }\end{array}$ \\
\hline & & $\begin{array}{l}\text { My decision-making in this } \\
\text { school is influenced by the } \\
\text { cultural composition of the } \\
\text { community. }\end{array}$ & $\begin{array}{l}\text { (Robson, Harken \& } \\
\text { Hill 2001) }\end{array}$ \\
\hline \multirow[t]{2}{*}{$\begin{array}{l}\text { Reasoned } \\
\text { Risk-taking in } \\
\text { Decision- } \\
\text { making }\end{array}$} & \multirow[t]{2}{*}{$\begin{array}{l}\text { Decisions made } \\
\text { that are contrary to } \\
\text { the policy and } \\
\text { procedures in the } \\
\text { regulatory } \\
\text { framework }\end{array}$} & $\begin{array}{l}\text { There have been instances } \\
\text { where compliance with the } \\
\text { framework was impossible } \\
\text { given the circumstances so } \\
\text { that I had to use professional } \\
\text { discretion to make decisions } \\
\text { that were contrary to stated } \\
\text { policy or procedures. }\end{array}$ & $\begin{array}{l}\text { (Trimmer 2003a) } \\
\text { (Trimmer 2003b) }\end{array}$ \\
\hline & & $\begin{array}{l}\text { I do not comply with policies } \\
\text { or procedures that I believe } \\
\text { are constraining activities in } \\
\text { my school. }\end{array}$ & $\begin{array}{l}\text { (Trimmer 2003a) } \\
\text { (Trimmer 2003b) }\end{array}$ \\
\hline
\end{tabular}




\begin{tabular}{|c|c|c|c|}
\hline Construct & $\begin{array}{l}\text { Key Issues } \text { from } \\
\text { Literature/ } \\
\text { research }\end{array}$ & $\begin{array}{l}\text { Proposed Items for Survey } \\
\text { Questionnaire }\end{array}$ & Reference/Source \\
\hline & & $\begin{array}{l}\text { I refer to the regulatory } \\
\text { framework after I have made } \\
\text { a decision to check whether it } \\
\text { complies with stated policies. }\end{array}$ & $\begin{array}{l}\text { (Trimmer 2003a) } \\
\text { (Trimmer 2003b) }\end{array}$ \\
\hline & & $\begin{array}{l}\text { There have been instances } \\
\text { where I have made a decision } \\
\text { that met the general intent of a } \\
\text { policy but where for some } \\
\text { reason, such as in the best } \\
\text { interest of a student(s), the } \\
\text { detailed mandatory } \\
\text { procedures were breached. }\end{array}$ & $\begin{array}{l}\text { (Soane \& Chmiel } \\
\text { 2005) } \\
\text { (Trimmer 2003a) } \\
\text { (Trimmer 2003b) }\end{array}$ \\
\hline & & $\begin{array}{l}\text { There have been any instances } \\
\text { where I had to use } \\
\text { professional discretion to } \\
\text { make a local decision that } \\
\text { breached the relevant policy } \\
\text { or procedures as they did not } \\
\text { allow flexibility to deal with } \\
\text { the circumstances of the } \\
\text { particular case or issue. }\end{array}$ & $\begin{array}{l}\text { (Soane \& Chmiel } \\
\text { 2005) } \\
\text { (Trimmer 2003a) } \\
\text { (Trimmer 2003b) }\end{array}$ \\
\hline & & $\begin{array}{l}\text { Making decisions that involve } \\
\text { risk is necessary to get ahead } \\
\text { and gain promotion. }\end{array}$ & $\begin{array}{ll}\text { (MacCrimmon } & \& \\
\text { Wehrung 1990) } & \end{array}$ \\
\hline & & $\begin{array}{l}\text { Effective decision-making } \\
\text { that meets the needs of the } \\
\text { school and community } \\
\text { requires principals to take } \\
\text { responsibility for taking risks. }\end{array}$ & $\begin{array}{l}\text { (Trimmer 2003a) } \\
\text { (Trimmer 2003b) }\end{array}$ \\
\hline & & $\begin{array}{l}\text { Strategic risk-taking is } \\
\text { essential to meet the outcomes } \\
\text { expected of principals and } \\
\text { schools. }\end{array}$ & $\begin{array}{l}\text { (Baird \& Thomas } \\
\text { 1985) } \\
\text { (MacCrimmon \& } \\
\text { Wehrung 1990) } \\
\text { (Soane \& Chmiel } \\
\text { 2005) }\end{array}$ \\
\hline & & $\begin{array}{l}\text { I never make decisions that } \\
\text { are contrary to the regulatory } \\
\text { framework. }\end{array}$ & $\begin{array}{l}\text { (Trimmer 2003a) } \\
\text { (Trimmer 2003b) }\end{array}$ \\
\hline & & $\begin{array}{l}\text { I feel pressured to make } \\
\text { decisions in line with the } \\
\text { regulatory framework even } \\
\text { when I don't believe it will } \\
\text { achieve the best result. }\end{array}$ & (Deci \& Ryan 1987) \\
\hline & & $\begin{array}{l}\text { If the experience of myself } \\
\text { and other principals I know in } \\
\text { similar situations indicates a } \\
\text { decision should be made } \\
\text { contrary to the stated policy I } \\
\text { will make a decision that } \\
\text { aligns with that experience } \\
\text { rather than the regulatory } \\
\text { framework. }\end{array}$ & $\begin{array}{l}(\text { Wirtz, Cribb \& } \\
\text { Barber 2005) }\end{array}$ \\
\hline
\end{tabular}




\begin{tabular}{|c|c|c|c|}
\hline Construct & $\begin{array}{l}\text { Key Issues from } \\
\text { Literature/ Past } \\
\text { research }\end{array}$ & $\begin{array}{l}\text { Proposed Items for Survey } \\
\text { Questionnaire }\end{array}$ & Reference/Source \\
\hline & & $\begin{array}{l}\text { Making decisions that can be } \\
\text { publicly and legally defended } \\
\text { is more important than the } \\
\text { content of the decision. }\end{array}$ & $\begin{array}{l}\text { (Wirtz, Cribb } \quad \& \\
\text { Barber 2005) }\end{array}$ \\
\hline & & $\begin{array}{l}\text { I have used professional } \\
\text { discretion to make decisions } \\
\text { that don't comply with stated } \\
\text { policy or procedures on } \\
\text { matters not related to students } \\
\text { such as maintenance, finance } \\
\text { and purchasing. }\end{array}$ & $\begin{array}{l}\text { (Trimmer 2003a) } \\
\text { (Trimmer 2003b) } \\
\text { Feedback from pilot } \\
\text { of the questionnaire }\end{array}$ \\
\hline & & $\begin{array}{l}\text { I have used professional } \\
\text { discretion to make decisions } \\
\text { that don't comply with stated } \\
\text { policy or procedures on } \\
\text { matters related to staff such as } \\
\text { relief, performance } \\
\text { management and substandard } \\
\text { performance. }\end{array}$ & $\begin{array}{l}\text { (Trimmer 2003a) } \\
\text { (Trimmer 2003b) } \\
\text { Feedback from pilot } \\
\text { of the questionnaire }\end{array}$ \\
\hline
\end{tabular}


Appendix B. Framework for Development of Questionnaire

\begin{tabular}{|c|}
\hline QUESTIONNAIRE \\
ID \\
\hline
\end{tabular}

Regulatory framework decision-making by principals

Thank you for taking the time to answer this survey.

Please be assured that your answers are strictly confidential. I will be the only person who will see your individual responses. The survey questionnaires will not be shown to or become the property of the Department of Education and Training. The published results will not identify any individual or school.

For most questions, all you need to do is tick the box which most applies to you.

Please use the rely paid envelope (it doesn't need a stamp) to return the survey to me by

29 September 2006. Your assistance and participation are greatly appreciated.

\section{Demographic Information:}

1. Your gender?

\begin{tabular}{|l|l|}
\hline Male & Female \\
\hline & \\
\hline
\end{tabular}

2. Your age range?

\begin{tabular}{|l|l|l|l|l|}
\hline Up to 30 & 30 up to & $\begin{array}{l}40 \\
40\end{array}$ & up to & 50 or over \\
\hline & 40
\end{tabular}

3. Highest level of education achieved?

\begin{tabular}{|l|l|l|l|}
\hline Bachelor & $\begin{array}{l}\text { Post Grad } \\
\text { Diploma }\end{array}$ & Masters & Doctorate \\
\hline & & & \\
\hline
\end{tabular}

4. Do you hold the role of principal substantively?

\begin{tabular}{|l|l|}
\hline yes & no \\
\hline & \\
\hline
\end{tabular}

5. How long have you been employed in the role of principal?

\begin{tabular}{|c|c|c|c|}
\hline $\begin{array}{l}\text { Less than } \\
1 \text { year }\end{array}$ & $\begin{array}{l}1 \quad \text { to } 2 \\
\text { years }\end{array}$ & $\begin{array}{l}>2 \text { to } 5 \\
\text { years }\end{array}$ & $\begin{array}{l}\text { More } \\
\text { than } \\
5 \text { years }\end{array}$ \\
\hline & & & \\
\hline
\end{tabular}

6. How long have you been employed as a teacher/school administrator?

\begin{tabular}{|c|c|c|c|}
\hline $\begin{array}{l}\text { Less than } \\
5 \text { years }\end{array}$ & $\begin{array}{l}>5 \text { to } 10 \\
\text { years }\end{array}$ & $\begin{array}{l}>10 \text { to } 20 \\
\text { years }\end{array}$ & $\begin{array}{ll}\text { More } & \\
\text { than } & 20 \\
\text { years } & \\
\end{array}$ \\
\hline & & & \\
\hline
\end{tabular}

7. District? 
8. The location of my school is

9. School Type

\begin{tabular}{|l|l|l|l|l|}
\hline Remote & Rural & $\begin{array}{l}\text { Regional } \\
\text { Centre }\end{array}$ & Metro \\
\hline Primary & $\begin{array}{l}\text { District } \\
\text { High }\end{array}$ & $\begin{array}{l}\text { Secondar } \\
\mathbf{y}\end{array}$ & $\begin{array}{l}\text { Agricult } \\
\text { ural } \\
\text { College }\end{array}$ & $\begin{array}{l}\text { Senior } \\
\text { College }\end{array}$ \\
\hline & & & & \\
\hline
\end{tabular}

10. School size (number of students)

11. The proportion of students at this school who are of Aboriginal or Torres Strait Islander descent is $\%$

12. The proportion of students at this school who are from culturally and linguistically diverse backgrounds is $\%$

\section{Regulatory Framework Decision-making}

\begin{tabular}{|c|c|c|c|c|c|}
\hline & & 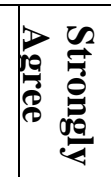 & $\underset{8}{\stackrel{8}{8}}$ & 焉. & 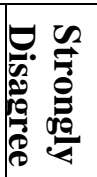 \\
\hline 13. & $\begin{array}{l}\text { The principal is accountable for ensuring that decisions are made in } \\
\text { line with the School Education Act and Regulations and policy } \\
\text { included in the regulatory framework }\end{array}$ & & & & \\
\hline 14. & $\begin{array}{l}\text { The regulatory framework constrains me in my role of principal in } \\
\text { making decisions that meet the needs of this school and its students }\end{array}$ & & & & \\
\hline 15. & As principal, I have control over decision-making in the school & & & & \\
\hline 16. & $\begin{array}{l}\text { The consequences of decisions made in line with the regulatory } \\
\text { framework are beyond my control }\end{array}$ & & & & \\
\hline 17. & $\begin{array}{l}\text { Principals have the authority to choose the appropriate course of } \\
\text { action for the circumstances in their school }\end{array}$ & & & & \\
\hline 18. & Authority to make decisions is delegated to principals & & & & \\
\hline 19. & $\begin{array}{l}\text { The purpose of the regulatory framework is to assure compliance by } \\
\text { schools to established policies and procedures }\end{array}$ & & & & \\
\hline 20. & $\begin{array}{l}\text { It is important that principals in all schools are making consistent } \\
\text { decisions }\end{array}$ & & & & \\
\hline 21. & $\begin{array}{l}\text { In making decisions I am obligated to comply with courses of action } \\
\text { prescribed in the regulatory framework }\end{array}$ & & & & \\
\hline
\end{tabular}




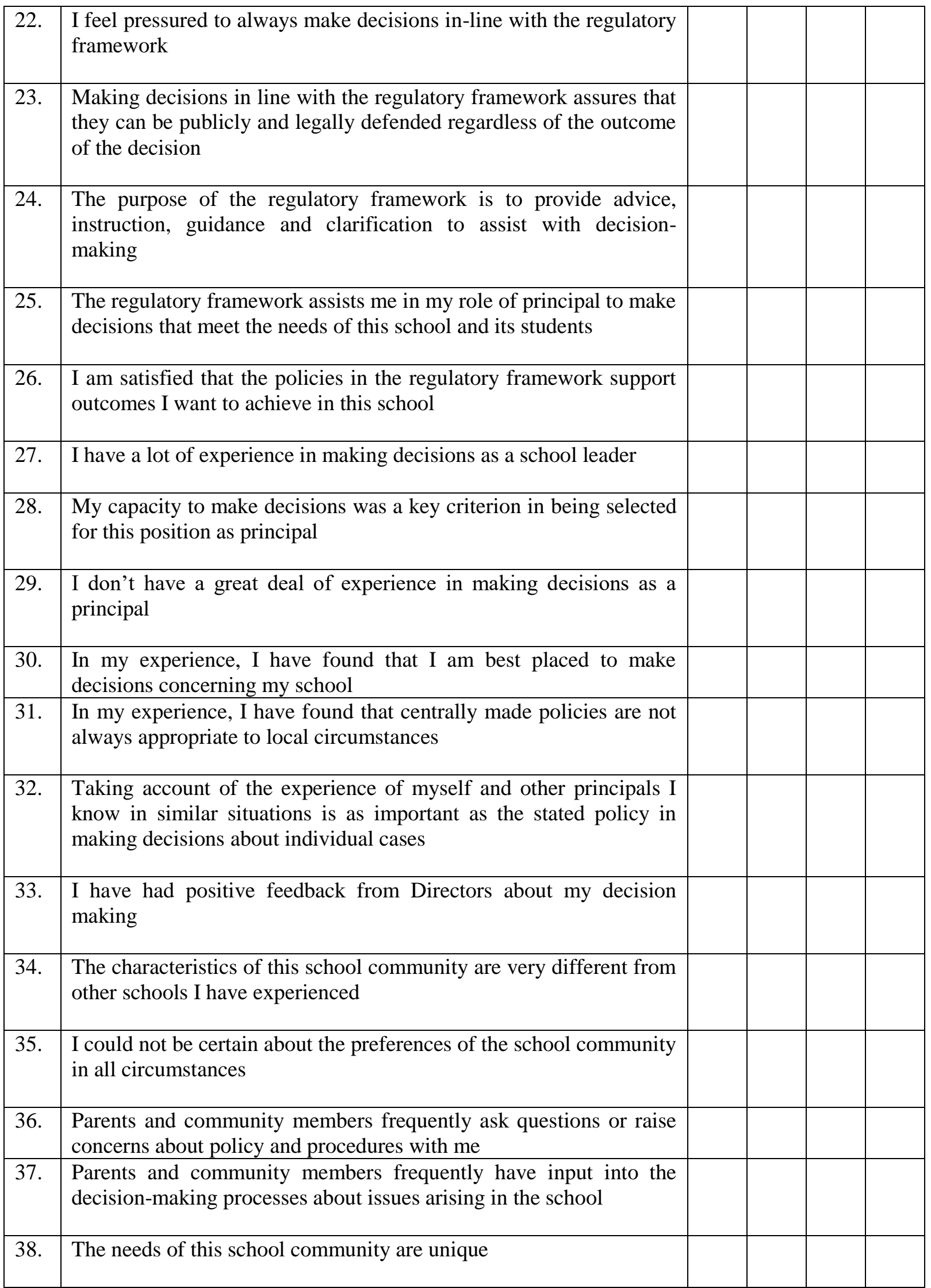




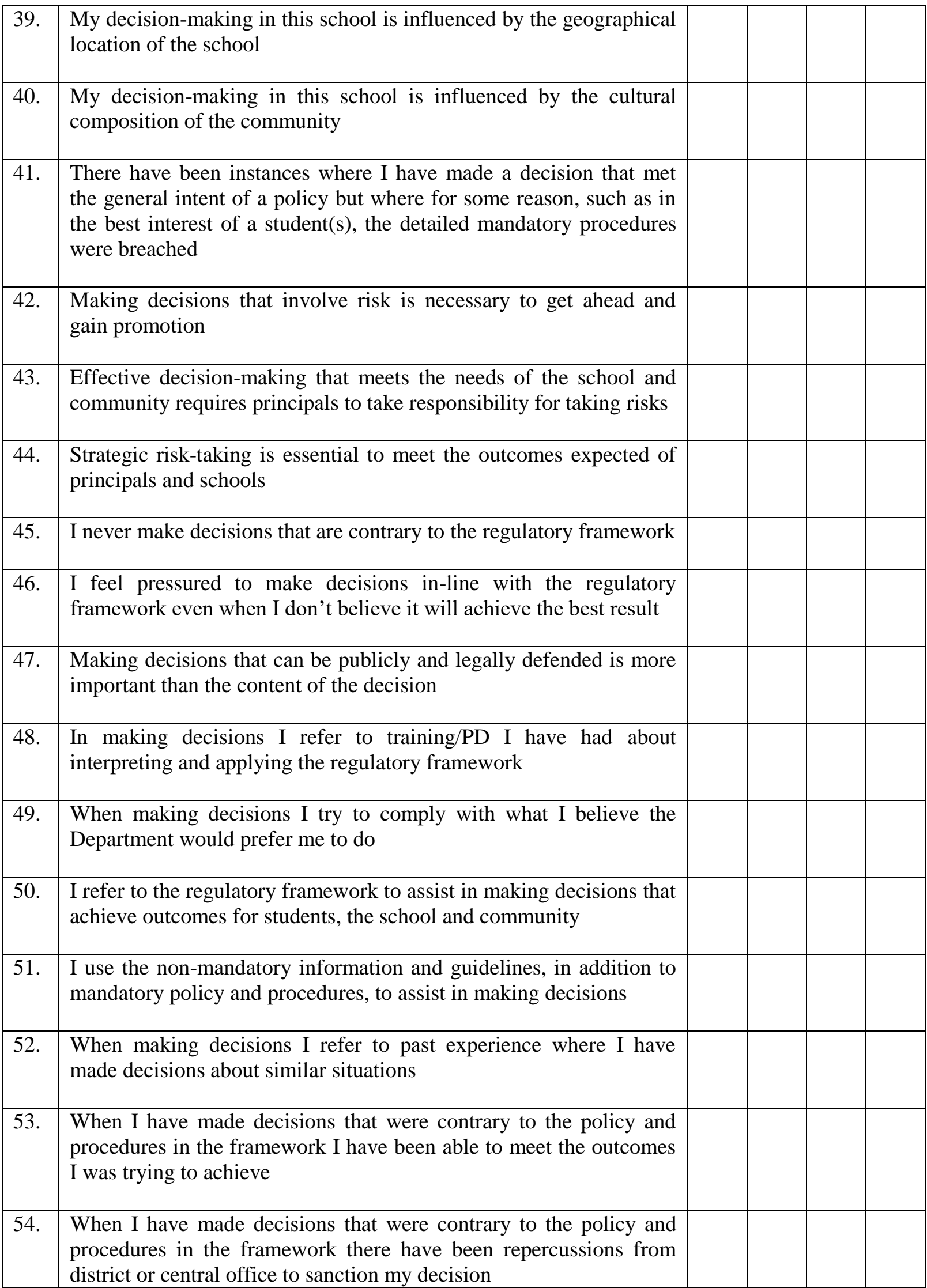




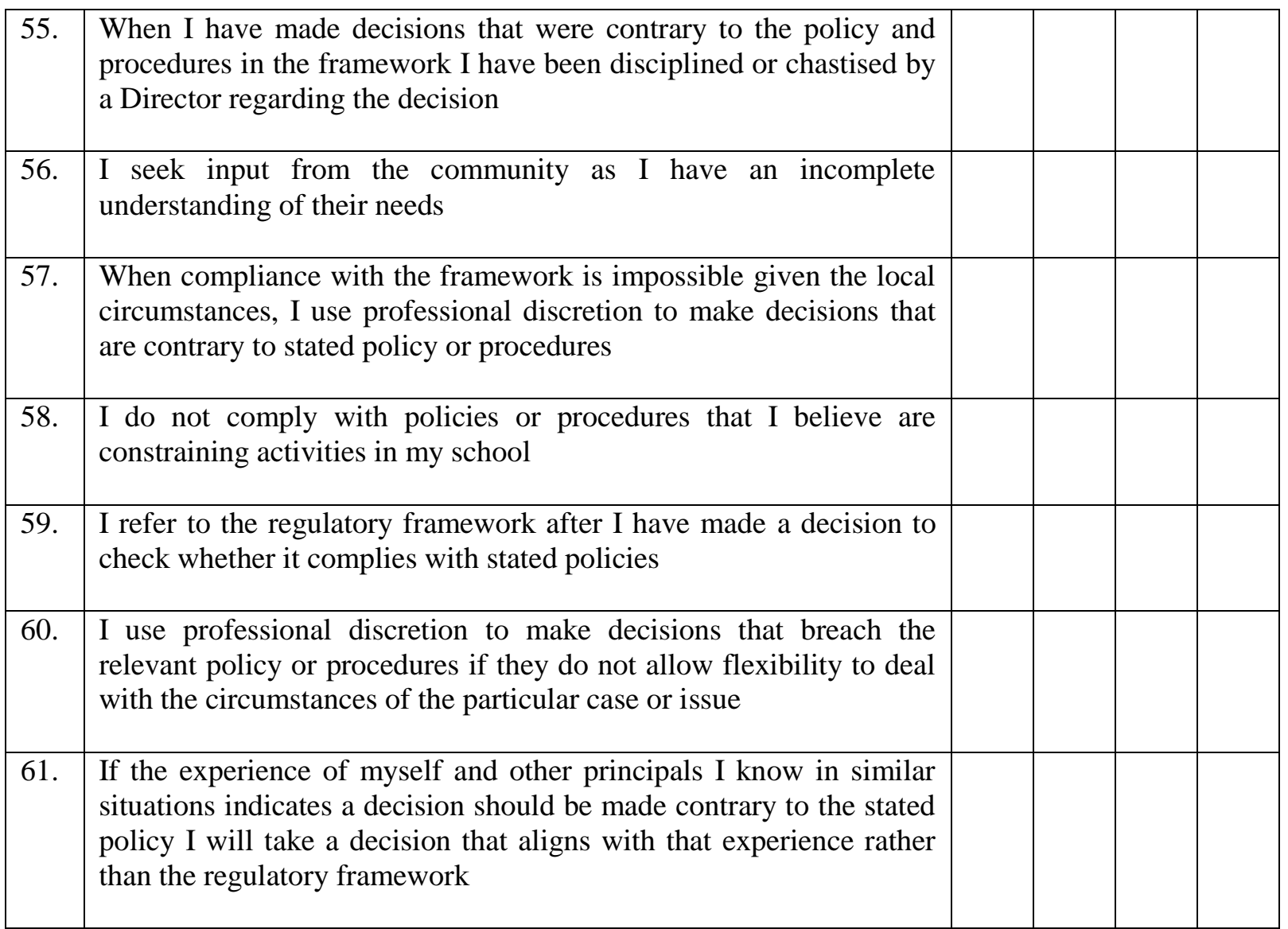


